\title{
The Relationship between Youth Violence, Victimization, and Educational Outcomes
}

\author{
Andrew R. Wilczak \\ Division of Behavioral and Social Sciences, Wilkes University, Wilkes-Barre, USA \\ Email: Andrew.wilczak@wilkes.edu \\ Received 11 August 2014; revised 26 September 2014; accepted 7 October 2014 \\ Copyright (C) 2014 by author and Scientific Research Publishing Inc. \\ This work is licensed under the Creative Commons Attribution International License (CC BY). \\ http://creativecommons.org/licenses/by/4.0/ \\ (c) (i) Open Access
}

\begin{abstract}
Prior research on the relationship between adolescent violence, victimization, and educational attainment has largely focused on the relationship between victimization experiences and later educational outcomes. Lost in this line of inquiry is a) the relationship between one's own violent behavior and later educational outcomes and $b$ ) the overlap between being a victim and being a perpetrator. The aim of this project is to address those limitations in the literature. Findings show that being both a victim and perpetrator of violence significantly increase the risk of dropping out of school and not attending college. Both aspects of violence have their own unique negative effect on the risk of limited future attainment. While this does not suggest that these youth are definitively at risk for limited achievement later in life, it does suggest that their path to future success is severely inhibited by these violent experiences.
\end{abstract}

\section{Keywords}

Violence, Victimization, Education, Adolescence

\section{Introduction}

One of the most significant advances in life-course criminology stems from the work of Macmillan (2000), who began to look at how violent victimization could disrupt later well-being by focusing on the financial cost of victimization. Later, Macmillan (2001) and Macmillan and Hagan (2004) demonstrated that adolescent violent victimization could lead to future socioeconomic distress. Furthermore, Hagan and Foster (2001) and Haynie, Petts, Maimon, and Piquero (2009) demonstrated that exposure to violence in adolescence could trigger a premature entry into adult roles, which might include leaving school and entering the work force.

However, in spite of this growing area of research on the relationship between violent victimization and socioeconomic development, little research has been conducted to explore any direct relationship between violent 
perpetration and later socioeconomic status. In many cases, the relationship between violence and later socioeconomic success in framed in terms of incarceration, wherein violence increases the likelihood of being institutionalized, which in turn reduces the options and opportunities for later attainment (Bernburg \& Krohn, 2003). Others have demonstrated that antisocial behavior during childhood can predict a multitude of similarly negative outcomes later in life, including failure to achieve educationally (Sampson \& Laub, 1992). But violence itself has never been singled out as a specific type of antisocial behavior in this regard, and there has been little discussion about the possible mechanisms behind this connection.

The goal of this paper is to examine the relationship between violence and victimization and educational attainment. Using data from the first and third waves of the National Longitudinal Study of Adolescent Health, this study aims to assess the relationship between adolescent violence, victimization and status attainment by examining how violence and victimization influence the odds of limited educational achievement.

\section{Literature Review}

\subsection{Victimization and Educational Attainment}

Macmillan (2000) studied the financial costs of violent victimization using data from the National Youth Survey and the 1993 Canadian General Social Survey. Macmillan found that violent victimization can be costly in a variety of ways. First, victimization has the greatest negative effect on adolescents. Second, violent victimization in adolescence can disrupt later status attainment by influencing mechanisms involved in both the educational and occupational attainment process. Finally, the financial costs of violent victimization in adolescence are considerably greater than previously believed. Indeed, Macmillan and Hagan (2004) argue that experiencing violent victimization during adolescence can spark a chain reaction, by which victimization reduces educational self-efficacy, which in turn reduces educational performance and later status attainment.

Another possible explanation for why violent victimization may lead to reduced educational success and ultimately weaker socioeconomic status is posited by Hagan and Foster (2001) and Haynie and colleagues (2009). This line of inquiry argues that victimization during adolescence may trigger a premature exit from adolescence into adulthood, which can include sudden shifts in mental health, suicidality, running away from home, pregnancy, and dropping out of school to enter into the work force. It may even be the case that the net effect of these other non-normative transitions—especially parenthood and leaving home-could and likely does reduce the likelihood of future educational and economic success. It may also be the case that the reduction in mental health associated with victimization also reduces the ability of the individual to perform well in school.

\subsection{The Relationship between Violence and Educational Attainment}

Bernburg and Krohn (2003) assess the life course consequences of being formally labeled as an offender, and find that not only does formal intervention lead to increased likelihood of future involvement in crime and delinquency, but official intervention can trigger a series of events which serve to reduce the likelihood that the offender will be employed in any legitimate way in adulthood. Specifically, the authors show that official intervention can reduce the likelihood that the offender will graduate from high school and increase the likelihood that they will be unemployed for significant periods of time, both of which contribute to the likelihood that they will be selling drugs in the future. Bernburg and Krohn use drug dealing as a separate dependent variable above and beyond general crime to model for criminality which may be strictly economically motivated. Because their measure of general crime includes variables indicating various degrees of theft, it is reasonable to conclude that their analyses suggest official intervention in adolescence can lead to multiple forms of illegitimate employment in adulthood via disrupting educational attainment and leading to sustained periods of unemployment. Bernburg, Krohn and Rivera (2006) also show that incarcerated individuals are exposed to a wider variety of criminal and deviant possibilities than they themselves were engaged in previously, which not only increases the likelihood that they will offend in the future, but also normalizes their behavior — both of which likely reduces their educational and socioeconomic prospects.

\subsection{Violence, Victimization and Educational Attainment}

Based on prior research, it is reasonable to believe that individuals who are severely victimized and extremely violent will experience substantially higher odds of failure to achieve educational success. However, it may also 
be the case that an entirely different process is at work. Drawing on the work of Rosenberg, Schooler, and Schoenbach (1989), the effects that violence and victimization have on the self-concept may balance each other out, such that the negative effect of victimization on self-efficacy is buffered by the potential positive benefit of violence on self-esteem.

\subsection{Theoretical Processes}

There are a number of theoretical explanations as to why violence and victimization should reduce educational achievement. Several of these mechanisms have already been mentioned-labeling, learning, and the life course perspective all offer plausible explanations why violence and victimization can influence educational achievement. General strain theory (Agnew, 1992; Agnew, 2001) may also explain why victimization reduces educational achievement. Adolescents who are victimized may perceive their victimization as unjust; if they are victimized frequently, then the stress they experience as a result will likely be higher in magnitude. This may then lead to criminal coping, which increases the risk of criminal justice contacts, incarceration, and ultimately being removed from the educational system. Less severe, this stress may trigger the reductions in educational self-efficacy discussed by Macmillan and Hagan (2004).

A symbolic interactionist approach can also shed light on how violence may reduce emerging socioeconomic status. Matsueda and Heimer (1997) argue that boys and girls value school and delinquent behaviors differently_-girls place more value on education, and boys place more value on delinquency. If this is indeed the case, violence may be associated with reduced educational achievement not because there is something passive about violent perpetration in of itself that leads to poor achievement, but simply that the individual is more concerned with violence itself — not just the act of being violent, but developing and maintaining a violent reputation — than doing well in school. This stems from the neo-Meadian perspective developed by Giordano, Schroeder, and Cernkovich (2007), who argue that the reasons why an individual comes to value different behaviors positively or negatively —in this instance, being violent versus being educationally adept-comes from the interactions with people around us and is something we learn over time. This same line of thinking can be applied to victimization as well. Aside from the physical pain experienced, individuals have to learn that the experience itself and the consequences of it—being labeled as weak, being disrespected, etc-is something that they do not want to happen and is something that they should not think of in a positive manner.

Yet another possibility, and a competing hypothesis tested in these analyses, is the role of low self-control (Gottfredson \& Hirschi, 1990). Individuals with low self-control may be more likely to engage in violence, and their inability to stay out of risky or dangerous situations may increase their risk of victimization. Furthermore, adolescents with low self-control may also have greater difficulty navigating the educational system and remaining committed to educational achievement throughout their lives. It is a process that demands delaying gratification for years, and for a teen with low self-control, the only conceivable method of skipping to the end is through working so hard that they are able to pass over entire grades, or, more likely, dropping out or at least leaving permanently after high school.

\subsection{Revisiting the Relationship between Violence and Victimization}

As past research has indicated, violence and victimization significantly overlap with one another in a number of ways (Lauritsen, Sampson, \& Laub, 1991; Schreck, Stewart, Osgood et al., 2008). It may be the case that adolescent violence and victimization reduce the likelihood of educational success because of their relationship with future violent experiences. This speaks to a number of theoretical processes outlined previously—because violence begets violence, this may speak to a normalization of these behaviors (Bernburg et al., 2006; Giordano et al., 2007), a constant exposure to stress (Agnew, 1992), an accumulation of disadvantage (Hagan and Foster, 2003), stability of low self-control (Gottfredson \& Hirschi, 1990), or consistency in values of the individual (Matsueda \& Heimer, 1996). To account for the possibility that adolescent violence and victimization indirectly influence educational achievement via their relationship with future violence and victimization, these analyses will include violence and victimization in early adulthood as well as in adolescence.

\subsection{Hypothesis}

The hypothesis of the current study is that both violence and victimization will significantly increase the odds of dropping out of school and decrease the odds of going to college. Both forms of violence should reduce educa- 
tional achievement for reasons cited in previous research; victimization can reduce educational self-efficacy (Macmillan \& Hagan, 2004); perpetration may lead to incarceration, which by definition reduces educational opportunities can reinforce the individual's criminal or deviant identity, which in turn reduces the likelihood that they will be engaging in any future pro-social status attainment processes (Bernburg et al., 2003; Bernburg et al., 2006).

\section{Research Methods}

\subsection{Sample}

This study uses data from the first and third waves of the National Longitudinal Study of Adolescent Health (AddHealth). AddHealth is a school-based, nationally representative, stratified random sample of adolescents living in the United States. The first round of data collection occurred in 1994-1995, and the third round of data collection occurred in 2001.

There are a number of reasons why Wave 2 was excluded from this study. First, use of the second wave of AddHealth excludes almost four-thousand high school seniors who had graduated since the first wave, whose emerging socioeconomic status is vital to this study. Second, the overarching goal of this study is to examine how violent perpetration and victimization jointly affect adolescent development with a focus on emerging adulthood. The majority of the respondents in these data are in this period of the life course in the third wave of these data. While future research that uses data from the fourth wave of Add Health will be beneficial in helping us understand how adolescent violence and victimization can affect achieved socioeconomic attainment in adulthood, the purpose of this paper is to focus solely on that the first step in the process. Missing data is handled using multiple imputation (Royston, 2004). The final sample size is 14,322. The survey weights provided by AddHealth are used to account for the complex nature of these data.

\subsection{Measures}

The dependent variable is the respondent's level of educational achievement. This measure was created using a question in the AddHealth questionnaire at Wave 3 that asks the how many years of education they have. This variable was collapsed to indicate whether or not the respondent had failed to complete high school (11 or fewer years of education), completed high school but did not go to college (12 years of education), and some college experience (13 or more years of education). However, it is possible that this measure may not be an accurate representation of the respondent's educational attainment or lack thereof. It is possible that some respondents misinterpreted the original question and only responded with the number of years of post-secondary education they have received (in other words, a value of 7 may indicate 7 years of college and postgraduate education, and not dropping out in the 7th grade). It is also possible that some of these respondents followed nontraditional educational trajectories, like dropping out of school only to complete a General Education Diploma (GED) and eventually go to college. Finally, because so many of these respondents are in their early 20s, it is difficult to know with certainty what their educational achievement will ultimately be. However, this is not the stated purpose of this paper and is something that should be addressed by future research.

The focus of these analyses is on two levels of educational achievement in part because these respondents are so young, and the indicators selected represent statuses that the majority of them have had the opportunity to take on. It is worthwhile to approach the question of how violence and victimization influence emerging socioeconomic status from multiple directions, to avoid assuming that the relationship between violence and victimization and dropping out of school is the same as the relationship between violence, victimization and going to college.

Violent perpetration is measured at both waves. This is a 5 item scale that asks the respondent whether or not they shot or stabbed someone, whether or not they carried a weapon to school (this item is modified to say school or work at Wave 3), whether or not they pulled a weapon on someone without using it, whether or not a group of their friends got into a fight with another group of people, and whether or not the respondent ever used a weapon to take something from someone by force. Each of these items refers to the respondent's behavior in the past 12 months, with the exception of the question asking if they carried a weapon to school or work, which reflects the past 30 days at Wave 1 and the past 12 months at Wave 3. Each item is dichotomized, and then all are summed. Because the resulting measure was severely skewed, it was collapsed into a three-level variable in- 
dicating whether or not the respondent engaged in no violence (0), a low level of violence (1 act), or a high level of violence ( 2 or more acts). It is possible that not all of these variables represent direct violent acts, nor do they all speak to the agency of the participant. For instance, there are some schools where bringing weapons might be common — not because of violence happening in the school, but because students are using their time before and after school to hunt. However, it may also be the case that people who did bring guns or knives to school (or work) for use in this capacity would necessarily think that they brought a weapon to school. Excluding this question would cut out students who brought weapons to school for any number of reasons related to their use in harming (or threatening to harm) other people in a public setting.

Violent victimization is also measured at both waves. Respondents are asked how often in the past 12 months they were shot, stabbed, had a weapon pulled on them, or were jumped. These measures were dichotomized and summed to create the final variable. There is a slight difference in these variables at each wave. At Wave 1, respondents are asked if someone pulled a knife or gun on them; at Wave 3, there is one item asking if they have had a gun pulled on them, and one measure asking if they have had a knife pulled on them. Also, at Wave 1 respondents are asked only if they have been jumped, while at Wave 3 they are asked if they have been beaten up and nothing was taken from them, and if they were beaten up and something was taken from them. This variable is identical to the measure of violent perpetration, where a value of 0 means the respondent was never victimized, 1 means they experienced a low level/single instance of victimization, and 2 means they experienced a high level of victimization.

At each wave, the respondents are asked about their own involvement in violence and their own victimization experiences with regard to the immediate past. As discussed, the majority of these items refer to the past year. This is important to note, because the violent perpetration and victimization measures at Wave 3 should represent new events, and not the respondent's accumulation of violent experiences or their own memories of something that happened to them when they were younger.

The next question, then, is what proportion of the youth surveyed in these data were only victims, were only offenders, and experienced some degree of each? In the raw data, there are 2542 respondents who were only offenders at Wave 1 (17.94\%), 902 who were only victims at Wave 1 (6.36\%), and 1854 who were victims and offenders at Wave 1 (13.08\%). Altogether, 37.381\% of the respondents had some violent experience at Wave 1. At Wave 3, 1203 (8.603\%) of respondents are only violent, 490 are only victimized (3.5\%), and 600 (4.29\%) are both victims and offenders.

Controls: the following variables are included as controls from Wave 1 and are used throughout these analyses: age, age squared, gender, race/ethnicity, urbanicity, neighborhood disadvantage, family socioeconomic status (SES), and family structure, grade point average, and self-control. Age is the age of the respondent in years, ranging from 13 to 19 years old. Age squared is the square of age. Gender is a dummy variable that indicates whether or not the respondent identifies as female. Race/ethnicity is a series of dummy variables, indicating whether or not the respondent self-identifies as non-Hispanic black, Asian, or Hispanic. Non-Hispanic White is the contrast category. Urbanicity is a series of dummy variables that indicates whether or not the respondent attended a school located in an urban or suburban area at Wave 1. Attending a school located in a rural area is the contrast category. Urbanicity is included as a control because violent perpetration and victimization may have a different meaning depending on the context in which they are occurring; this is the "code of the streets" hypothesis (Anderson, 1999). Neighborhood disadvantage was developed using three 1990 census tract level variables taken from the Add Health Contextual Data: the proportion of families living below the poverty line, the proportion of males who were unemployed, and the proportion of households receiving public assistance. In earlier versions of this study, the measure of neighborhood disadvantage was the average of these three measures. Because neighborhood disadvantage was so strongly associated with educational attainment, this measure variable was recoded into a dummy variable that indicates whether or not the respondent fell into the top $25 \%$ of disadvantaged neighborhoods. Family SES is a composite of the respondent's parents education and occupation status (alpha = .742) (Bearman \& Moody, 2004). In addition to including this variable as a control because it indicates family social class, parental education is also associated with higher levels of educational achievement and aspiration (Sewell \& Shah, 1968). Family structure is a dummy variable where 1 indicates that both of the respondent's biological parents are in the home, and 0 indicates all other family structures. Past research (Demuth \& Brown, 2004; Apel \& Kaukinen, 2008) has indicated that family structure can influence future delinquency. GPA is constructed using the respondent's self-reports on their grades in science, math, history, and English courses. These items were recoded so higher values corresponded with higher grades in the course, and 
the final GPA measure is the average of these four responses. For those respondents who only gave valid answers on 2 or 3 classes, GPA was constructed by averaging only those responses. For respondents who only gave 1 valid response, GPA was coded as missing. Low self-control is a scale composed of five measures relating to the respondent's abilities to perform in school and their perception of their own behavior. This includes questions regarding their ability to focus in class and on their homework, as well as whether or not they believe they're doing everything in life just about right. These are the same measures used by Perrone, Sullivan, Pratt and Margaryan (2004). The resulting scale ranges from 1 to 20, with higher values indicating lower self-control. As discussed previously, based on prior research, individuals who have low impulse control should be more likely to quit school, while individuals with high self-control should be more likely to go to college.

Table 1 displays the weighted means and standard deviations for these measures. Among the focal variables, it is important to note that these respondents are, in general, desisting from both their being violent and being victims of violence. The average level of victimization decreases from .266 at Wave 1 to .102 at Wave 3. The average level of violent perpetration decreases from .443 at Wave 1 to .180 at Wave 3. This is consistent with the general notion of the age-crime curve. The respondents are also less depressed at Wave 3 , consistent with the idea that depression peaks in adolescence and gradually declines or levels off thereafter. There is also a fair amount of educational diversity at Wave 3. The mean value of 1.378 suggests that, on average, these respondents have completed high school and are pursuing some sort of college education. In fact, approximately one-third (4717) of these youth stopped their educational pursuit at high school; while over half (7829) are currently enrolled in or have completed college. 1764 (12.33\%) of these respondents did not complete high school.

Of the control variables, there are a few things worth mentioning. First, these respondents are between the ages of $11-21$ at Wave 1 and $18-28$ at Wave 3. This study is focused solely on adolescence and the transition to adulthood, and not on all violence and victimization occurring in society. Second, there are several potential mediating measures used in these analyses that should be highlighted. Regarding the connection between past and future serious violence, one possibility is that this is tied into neighborhood context and family poverty (Anderson, 1999). The neighborhood poverty measure used here is the average of the proportion of families receiving public assistance, the proportion of families whose income is below the poverty line, and the male unemployment rate. This final measure indicates that $9.5 \%$ of households (for lack of a better term) on average are impoverished in a given census tract. Across levels of family SES, the lowest quartile of families live in neighborhoods where the poverty rate ranges from approximately $12 \%-15.5 \%$, while the highest quartile live in neighborhoods where poverty averages $6 \%-7 \%$. Remember that this measure of family SES is not directly indicative of wealth, but the respondent's parent's occupational prestige and own education—indicators of cultural and social capital associated with greater socioeconomic strength.

Another possibility is that those youth who are violent, who are victimized, and who experience limited socioeconomic attainment may have low self-control. The measure of self-control included in these analyses taps directly into school performance. This variable is skewed, and there are very few individuals with extremely low self-control (values of 10 or higher represent a small percentage of these respondents). It may also be the case that limited educational attainment is directly related to poor academic performance. These respondents have approximately a B-/C+ average in their English, math, science, and history courses at Wave 1 . The most violent and the most severely victimized youth do have a lower GPA and less self-control at Wave 1 than their nonviolent peers. All violent youth have a GPA of 2.576 at Wave 1; nonviolent youth have a GPA of 2.927. Victimized youth have a GPA of 2.502; nonvictimized youth have a GPA of 2.888. The differences in self-control are more pronounced, with violent and victimized youth at approximately 6.8 on this scale, while their peers have a self-control value of approximately 5 on this scale. These differences are all significant at the $p<.001$ level.

The means and standard deviations for all of these variables for two subsets of these dataare also included: all violent youth and all victimized youth. Note that these are not necessarily the same as the measures of violence and victimization used in the analyses; here, all offenders and all victims are combined into one group in order to assess how these populations differ from the whole. In general, these groups do not differ in any unexpected ways. Each experiences higher levels of the corresponding form of violence than the full sample; each group is more depressed than average, has lower educational achievement than average, experience worse socioeconomic conditions, are more impulsive, and do not do as well in school. Each of these groups is predominantly male and has a higher proportion of non-white youth in comparison to the full sample. The corresponding levels of violent perpetration and victimization are small at Wave 3, which may create problems concerning statistical power in some of these analyses. As mentioned previously, there are enough violent and victimized youth at Wave 1 to 
Table 1. Means and standard deviations ${ }^{1}$.

\begin{tabular}{|c|c|c|c|}
\hline & Full sample & All violent youth & All victimized youth \\
\hline Variable & $\begin{array}{l}\text { Mean } \\
\text { (S.D.) }\end{array}$ & $\begin{array}{l}\text { Mean } \\
\text { (S.D.) }\end{array}$ & $\begin{array}{l}\text { Mean } \\
\text { (S.D.) }\end{array}$ \\
\hline \multicolumn{4}{|l|}{ Focal items } \\
\hline Violent victimization (W1) & $\begin{array}{c}.266 \\
(.581)\end{array}$ & $\begin{array}{c}.610 \\
(.782)\end{array}$ & - \\
\hline Violent victimization (W3) & $\begin{array}{c}.102 \\
(.366)\end{array}$ & $\begin{array}{l}.186 \\
(.481)\end{array}$ & $\begin{array}{c}.236 \\
(.553)\end{array}$ \\
\hline Violent perpetration (W1) & $\begin{array}{c}.443 \\
(.705)\end{array}$ & - & 1.105 \\
\hline Violent perpetration (W3) & $\begin{array}{c}.180 \\
(.490)\end{array}$ & $\begin{array}{c}.323 \\
(.634)\end{array}$ & $\begin{array}{c}.349 \\
(.652)\end{array}$ \\
\hline Educational attainment & $\begin{array}{l}1.378 \\
(.724)\end{array}$ & $\begin{array}{l}1.169 \\
(.775)\end{array}$ & $\begin{array}{l}1.138 \\
(.775)\end{array}$ \\
\hline Depression (W1) & $\begin{array}{c}5.716 \\
(4.238)\end{array}$ & $\begin{array}{c}6.753 \\
(4.502)\end{array}$ & $\begin{array}{c}6.974 \\
(4.552)\end{array}$ \\
\hline Depression (W3) & $\begin{array}{c}4.491 \\
(4.054)\end{array}$ & $\begin{array}{c}4.986 \\
(4.309)\end{array}$ & $\begin{array}{c}5.007 \\
(4.342)\end{array}$ \\
\hline \multicolumn{4}{|l|}{ Controls } \\
\hline Female & $\begin{array}{c}.492 \\
(.500)\end{array}$ & $\begin{array}{c}.365 \\
(.481)\end{array}$ & $\begin{array}{c}.281 \\
(.450)\end{array}$ \\
\hline Hispanic & $\begin{array}{c}.118 \\
(.323)\end{array}$ & $\begin{array}{c}.140 \\
(.346)\end{array}$ & $\begin{array}{c}.167 \\
(.373)\end{array}$ \\
\hline Non-Hispanic Black & $\begin{array}{l}.158 \\
(.365)\end{array}$ & $\begin{array}{c}.194 \\
(.396)\end{array}$ & $\begin{array}{l}.209 \\
(.407)\end{array}$ \\
\hline Non-Hispanic Asian & $\begin{array}{l}.037 \\
(.188)\end{array}$ & $\begin{array}{c}.033 \\
(.178)\end{array}$ & $\begin{array}{c}.029 \\
(.167)\end{array}$ \\
\hline Non-Hispanic native American/other & $\begin{array}{l}.016 \\
(.125)\end{array}$ & $\begin{array}{c}.020 \\
(.142)\end{array}$ & $\begin{array}{l}.020 \\
(.141)\end{array}$ \\
\hline Age (W1) & $\begin{array}{l}15.943 \\
(1.808)\end{array}$ & $\begin{array}{l}15.834 \\
(1.752)\end{array}$ & $\begin{array}{l}16.168 \\
(1.752)\end{array}$ \\
\hline Age (W1) squared & $\begin{array}{l}257.464 \\
(57.931)\end{array}$ & $\begin{array}{l}253.796 \\
(56.015)\end{array}$ & $\begin{array}{l}264.469 \\
(56.687)\end{array}$ \\
\hline Age (W3) & $\begin{array}{l}21.822 \\
(1.867)\end{array}$ & $\begin{array}{l}21.714 \\
(1.813)\end{array}$ & $\begin{array}{l}22.063 \\
(1.823)\end{array}$ \\
\hline Age (W3) squared & $\begin{array}{l}479.692 \\
(81.926)\end{array}$ & $\begin{array}{l}474.775 \\
(79.419)\end{array}$ & $\begin{array}{l}490.101 \\
(80.649)\end{array}$ \\
\hline Urbanicity & $\begin{array}{l}.268 \\
(.443)\end{array}$ & $\begin{array}{l}.297 \\
(.457)\end{array}$ & $\begin{array}{c}.339 \\
(.474)\end{array}$ \\
\hline Neighborhood poverty & $\begin{array}{c}.095 \\
(.074)\end{array}$ & $\begin{array}{l}.103 \\
(.078)\end{array}$ & $\begin{array}{l}.108 \\
(.078)\end{array}$ \\
\hline Family SES & $\begin{array}{l}5.680 \\
(2.630)\end{array}$ & $\begin{array}{c}5.270 \\
(2.561)\end{array}$ & $\begin{array}{c}5.279 \\
(2.539)\end{array}$ \\
\hline Family structure & $\begin{array}{l}.561 \\
(.496)\end{array}$ & $\begin{array}{c}.499 \\
(.500)\end{array}$ & $\begin{array}{c}.443 \\
(.497)\end{array}$ \\
\hline GPA & $\begin{array}{l}2.811 \\
(.769)\end{array}$ & $\begin{array}{l}2.576 \\
(.761)\end{array}$ & $\begin{array}{l}2.502 \\
(.754)\end{array}$ \\
\hline Low self control & $\begin{array}{c}5.471 \\
(3.331)\end{array}$ & $\begin{array}{c}6.764 \\
(3.516)\end{array}$ & $\begin{array}{c}6.963 \\
(3.669)\end{array}$ \\
\hline
\end{tabular}

${ }^{1}$ These values are not calculated using the multiply imputed data. Multiple imputation does not significantly change the mean values for any of these measures. ${ }^{2}$ All means and standard deviations were calculated using those respondents who were interviewed at Wave 1 and Wave 3 only. The information for Wave 2 specific measures come from a dataset containing information from the respondents at all three waves. Consequently, some of these values do shift slightly, but not substantially.

allow me to frame the majority of this in terms of high vs. low vs. no violence or victimization. Moving forward, to fully understand how violent perpetration and victimization affect adolescent development, it may be necessary to reframe this in terms of how any violence or victimization affects the life course instead of how the degree of violence and victimization affects the life course.

\section{Results}

In Table 2, the focus is on the direct relationship between adolescent violence and victimization on limited 
Table 2. Multinomial logistic regression models educational attainment at Wave 3 using adolescent violent offending and victimization. Betas and odds ratios reported.

\begin{tabular}{|c|c|c|c|c|c|c|c|c|}
\hline & \multicolumn{4}{|c|}{$\begin{array}{c}\text { Dropping out } \\
\text { of school }\end{array}$} & \multicolumn{4}{|c|}{$\begin{array}{l}\text { High school } \\
\text { only }\end{array}$} \\
\hline Female & $\begin{array}{c}-.341^{* * *} \\
(.711)\end{array}$ & $\begin{array}{l}-.249^{* *} \\
(.780)\end{array}$ & $\begin{array}{l}-.226^{*} \\
(.798)\end{array}$ & $\begin{array}{l}-.197^{*} \\
(.821)\end{array}$ & $\begin{array}{c}-.212^{* * *} \\
(.809)\end{array}$ & $\begin{array}{c}-.177^{* *} \\
(.837)\end{array}$ & $\begin{array}{l}-.165^{*} \\
(.848)\end{array}$ & $\begin{array}{l}-.154^{*} \\
(.857)\end{array}$ \\
\hline Non-Hispanic Black & $\begin{array}{l}-.466^{* *} \\
(.627)\end{array}$ & $\begin{array}{c}-.493^{* * *} \\
(.610)\end{array}$ & $\begin{array}{c}-.528^{* * *} \\
(.590)\end{array}$ & $\begin{array}{c}-.532^{* * * *} \\
(.587)\end{array}$ & $\begin{array}{l}-.120 \\
(.887)\end{array}$ & $\begin{array}{l}-.135 \\
(.874)\end{array}$ & $\begin{array}{l}-.144 \\
(.866)\end{array}$ & $\begin{array}{l}-.148 \\
(.863)\end{array}$ \\
\hline Hispanic & $\begin{array}{l}-.091 \\
(.913)\end{array}$ & $\begin{array}{l}-.132 \\
(.876)\end{array}$ & $\begin{array}{l}-.126 \\
(.882)\end{array}$ & $\begin{array}{l}-.141 \\
(.868)\end{array}$ & $\begin{array}{l}-.104 \\
(.898)\end{array}$ & $\begin{array}{l}-.121 \\
(.886)\end{array}$ & $\begin{array}{l}-.119 \\
(.888)\end{array}$ & $\begin{array}{l}-.123 \\
(.884)\end{array}$ \\
\hline Asian & $\begin{array}{l}-.955^{* *} \\
(.385)\end{array}$ & $\begin{array}{l}-.946^{* *} \\
(.388)\end{array}$ & $\begin{array}{l}-.977^{* *} \\
(.376)\end{array}$ & $\begin{array}{l}-.968^{* *} \\
(.380)\end{array}$ & $\begin{array}{l}-.394 \\
(.675)\end{array}$ & $\begin{array}{l}-.398 \\
(.672)\end{array}$ & $\begin{array}{l}-.400 \\
(.670)\end{array}$ & $\begin{array}{l}-.402 \\
(.669)\end{array}$ \\
\hline Native American/other & $\begin{array}{l}-.498 \\
(.608)\end{array}$ & $\begin{array}{l}-.511 \\
(.600)\end{array}$ & $\begin{array}{l}-.561 \\
(.570)\end{array}$ & $\begin{array}{l}-.559 \\
(.572)\end{array}$ & $\begin{array}{l}-.292 \\
(.747)\end{array}$ & $\begin{array}{l}-.297 \\
(.743)\end{array}$ & $\begin{array}{l}-.322 \\
(.725)\end{array}$ & $\begin{array}{l}-.321 \\
(.725)\end{array}$ \\
\hline Age & $\begin{array}{l}-.711 \\
(.491)\end{array}$ & $\begin{array}{l}-.834 \\
(.434)\end{array}$ & $\begin{array}{l}-.861 \\
(.423)\end{array}$ & $\begin{array}{l}-.900 \\
(.407)\end{array}$ & $\begin{array}{c}-2.234^{* * *} \\
(.104)\end{array}$ & $\begin{array}{c}-2.253^{* * *} \\
(.105)\end{array}$ & $\begin{array}{c}-2.269^{* * *} \\
(.103)\end{array}$ & $\begin{array}{c}-2.272^{* * *} \\
(.103)\end{array}$ \\
\hline Age squared & $\begin{array}{c}.011 \\
(1.012)\end{array}$ & $\begin{array}{c}.014 \\
(1.014)\end{array}$ & $\begin{array}{c}.015 \\
(1.015)\end{array}$ & $\begin{array}{c}.016 \\
(1.016)\end{array}$ & $\begin{array}{l}.050^{* * *} \\
(1.051)\end{array}$ & $\begin{array}{l}.050^{* * *} \\
(1.051)\end{array}$ & $\begin{array}{l}.050^{* * *} \\
(1.052)\end{array}$ & $\begin{array}{l}.050^{* * *} \\
(1.052)\end{array}$ \\
\hline Family SES & $\begin{array}{c}-.368^{* * *} \\
(.692)\end{array}$ & $\begin{array}{c}-.370^{* * *} \\
(.691)\end{array}$ & $\begin{array}{c}-.366^{* * *} \\
(.694)\end{array}$ & $\begin{array}{c}-.367^{* * *} \\
(.693)\end{array}$ & $\begin{array}{c}-.218^{* * * *} \\
(.804)\end{array}$ & $\begin{array}{c}-.217^{* * *} \\
(.805)\end{array}$ & $\begin{array}{c}-.216^{* * * *} \\
(.806)\end{array}$ & $\begin{array}{c}-.216^{* * * *} \\
(.806)\end{array}$ \\
\hline Urbanicity & $\begin{array}{c}.187 \\
(1.205)\end{array}$ & $\begin{array}{c}.155 \\
(1.168)\end{array}$ & $\begin{array}{c}.173 \\
(1.189)\end{array}$ & $\begin{array}{c}.160 \\
(1.174)\end{array}$ & $\begin{array}{l}-.004 \\
(.996)\end{array}$ & $\begin{array}{l}-.013 \\
(.987)\end{array}$ & $\begin{array}{l}-.010 \\
(.990)\end{array}$ & $\begin{array}{l}-.013 \\
(.987)\end{array}$ \\
\hline Neighborhood poverty & $\begin{array}{l}.721^{* * *} \\
(2.056)\end{array}$ & $\begin{array}{l}.706^{* * *} \\
(2.025)\end{array}$ & $\begin{array}{l}.699^{* * *} \\
(2.011)\end{array}$ & $\begin{array}{l}.695^{* * *} \\
(2.003)\end{array}$ & $\begin{array}{l}.447^{* * *} \\
(1.564)\end{array}$ & $\begin{array}{l}.443^{* * *} \\
(1.558)\end{array}$ & $\begin{array}{l}.440^{* * *} \\
(1.552)\end{array}$ & $\begin{array}{l}.439^{* * *} \\
(1.551)\end{array}$ \\
\hline Lives with both biological parents & $\begin{array}{c}-.818^{* * *} \\
(.441)\end{array}$ & $\begin{array}{c}-.788^{* * *} \\
(.455)\end{array}$ & $\begin{array}{c}-.806^{* * *} \\
(.447)\end{array}$ & $\begin{array}{c}-.794^{* * *} \\
(.452)\end{array}$ & $\begin{array}{c}-.437^{* * *} \\
(.646)\end{array}$ & $\begin{array}{c}-.426^{* * *} \\
(.653)\end{array}$ & $\begin{array}{c}-.435^{* * *} \\
(.647)\end{array}$ & $\begin{array}{c}-.430^{* * * *} \\
(.651)\end{array}$ \\
\hline GPA & $\begin{array}{c}-1.546^{* * *} \\
(.213)\end{array}$ & $\begin{array}{c}-1.536^{* * *} \\
(.215)\end{array}$ & $\begin{array}{c}-1.528^{* * *} \\
(.217)\end{array}$ & $\begin{array}{c}-1.526^{* * * *} \\
(.217)\end{array}$ & $\begin{array}{c}-.952^{* * *} \\
(.386)\end{array}$ & $\begin{array}{c}-.945^{* * *} \\
(.388)\end{array}$ & $\begin{array}{c}-.941^{* * *} \\
(.390)\end{array}$ & $\begin{array}{c}-.939^{* * *} \\
(.391)\end{array}$ \\
\hline Self-control & $\begin{array}{l}.055^{* * *} \\
(1.057)\end{array}$ & $\begin{array}{c}.041^{* *} \\
(1.042)\end{array}$ & $\begin{array}{c}.030^{*} \\
(1.031)\end{array}$ & $\begin{array}{c}.027^{*} \\
(1.027)\end{array}$ & $\begin{array}{l}-.009 \\
(.991)\end{array}$ & $\begin{array}{l}-.014 \\
(.986)\end{array}$ & $\begin{array}{l}-.019 \\
(.981)\end{array}$ & $\begin{array}{l}-.020 \\
(.980)\end{array}$ \\
\hline \multicolumn{9}{|l|}{ Violence } \\
\hline Violent victimization (W1) & - & $\begin{array}{l}.371^{* * *} \\
(1.449)\end{array}$ & - & $\begin{array}{c}.178^{*} \\
(1.195)\end{array}$ & - & $\begin{array}{c}.164^{* *} \\
(1.179)\end{array}$ & - & $\begin{array}{c}.074 \\
(1.077)\end{array}$ \\
\hline Violent perpetration (W1) & - & - & $\begin{array}{l}.447^{* * *} \\
(1.564)\end{array}$ & $\begin{array}{l}.384^{* * *} \\
(1.468)\end{array}$ & - & - & $\begin{array}{l}.203^{* * *} \\
(1.225)\end{array}$ & $\begin{array}{l}.178^{* * * *} \\
(1.195)\end{array}$ \\
\hline Constant & $14.835^{*}$ & $16.179^{*}$ & $16.224^{*}$ & $16.684^{*}$ & $28.805^{* * *}$ & $28.988^{* * * *}$ & $29.067^{* * *}$ & $29.101^{* * *}$ \\
\hline
\end{tabular}

${ }^{*} p<.05 ;{ }^{* *} p<.01 ;{ }^{* * *} p<.001$

educational attainment in early adulthood. By themselves, violence and victimization are both associated with reduced educational achievement. Throughout these analyses, adolescent violence is associated with reduced educational attainment net of the controls. Violent teens are more likely to either drop out of school, or graduate from high school without going onto college. Here, a unit increase in violent perpetration increases the odds of dropping out of school by $55.8 \%$ and the odds of stopping at high school by $25.1 \%$. Violent victimization increases the risk of dropping out of school, but has no bearing on whether or not the individual stops their educa- 
tional career at high school once their own violent behaviors are taken into consideration. It appears that if individuals can overcome the initial stress and trauma of being victimized, they still have the potential to attain educational success.

The significance of several of the control variables included here speak to potential areas of future research — specifically, how social class may influence the relationship between violence, victimization and failure to achieve. In these analyses, violent perpetration and victimization are significantly associated to educational attainment, even when controlling for both neighborhood poverty and family socioeconomic status. These socioeconomic indicators are also related to educational attainment. It may be the case that individuals who are victimized or are violent and have access to the resources that come with socioeconomic strength-medical treatment, counseling, and so on-may be less likely to drop out of school than individuals who do not have access to these potential coping resources. Parents of violent adolescents also have the option of dealing with their teen's behavior through stricter educational programs, a resource unavailable to families in poverty. This is especially evident when dropping out of school — the most severe outcome-is looked at net of the other two potential outcomes. Youth living in the poorest neighborhoods are $29 \%$ more likely to drop out of school than finish high school or go to college, while a unit increase in family SES diminishes the risk of dropping out of school by $14 \%$. Future research that examines the role of family and neighborhood SES on the relationship between violence, victimization and status attainment would be vital to our understanding of how these factors influence adolescent development.

As for the possibility that any association between violence, victimization, and failure to achieve are explained instead by self-control, my findings do not support this hypothesis. Adolescents with low self-control are more likely to drop out of school, but violence and victimization are both significant in spite of this. Low self-control has no bearing on whether or not individuals stop at high school or not. Low self-control by itself does not account for the relationship between violent perpetration, violent victimization, and limited educational attainment.

The next stage of these analyses is to examine how the connection between past and future violence and victimization influences educational attainment. Rather than violent experiences in adolescence triggering an onset of stress and/or an accumulation of disadvantage, it may be the case that individuals who are violent in adolescence will remain violent throughout their lives, and this personality trait—being a life course persistent offender (Moffitt, 1993) —is what is limiting their educational attainment.

Table 3 compares the associations of contemporaneous violence and victimization with educational achievement with those of violence and victimization in adolescence. Without controlling for adolescent violence and victimization, violent perpetration in early adulthood is associated with a greater risk of dropping out of school, while contemporaneous victimization is associated with stopping at high school.

Consistent with my previous findings, low self-control is significantly associated with dropping out of school. When adolescent violence and victimization are included in the analysis, the associations between violent experiences at different ages and educational attainment becomes more complex. The risk of dropping out of school (versus going to college) is greater for individuals who were violent and/or victimized during adolescencecontemporaneous violent experiences do not appear to matter above and beyond earlier experiences. The likelihood of stopping at high school is also greater for those individuals who engaged in violence during adolescence. Violent victimization in early adulthood remains associated with stopping at high school when controlling for adolescent violent experiences.

Put differently, adolescent violence is clearly associated with disrupted educational trajectories. Even when accounting for the relationship between past and future violence, violent teens are more likely to drop out of school and/or end their educational careers at high school. This does not discount the possibility of some other type of educational trajectory - pursuing a GED, going to a technical school, etc. Violent victimization also increases the risk of limited educational achievement. In adolescence, victimized teens are more likely to drop out of school than go to college. Victimized young adults are also more likely to limit their educational paths to high school. In other words, violence affects education over the long term; victimization affects education immediately. That being said, it is difficult to draw too much from this conclusion, because of the timing of these events. There is the possibility that these supposedly contemporaneous instances of violent victimization occur after some of these respondents finished their high school education and decided not to pursue a college education. Therefore, instead of their victimization influencing their decision not to go to college, it may be the case that their conscious decision to stop their educational pursuits increased their risk of victimization by reducing 
Table 3. Multinomial logistic regression models predicting dropping out of high school and high school only at Wave 3 using violent offending and victimization in adolescence and early adulthood.

\begin{tabular}{|c|c|c|c|c|}
\hline & \multicolumn{2}{|c|}{$\begin{array}{c}\text { Dropping out } \\
\text { of school }\end{array}$} & \multicolumn{2}{|c|}{$\begin{array}{l}\text { High school } \\
\text { only }\end{array}$} \\
\hline Female & $\begin{array}{l}-.272^{* *} \\
(.762)\end{array}$ & $\begin{array}{l}-.164 \\
(.849)\end{array}$ & $\begin{array}{l}-.186^{* *} \\
(.830)\end{array}$ & $\begin{array}{l}-.144^{*} \\
(.866)\end{array}$ \\
\hline Non-Hispanic Black & $\begin{array}{l}-.500^{* *} \\
(.607)\end{array}$ & $\begin{array}{c}-.551^{* * *} \\
(.577)\end{array}$ & $\begin{array}{l}-.135 \\
(.874)\end{array}$ & $\begin{array}{l}-.156 \\
(.855)\end{array}$ \\
\hline Hispanic & $\begin{array}{l}-.094 \\
(.910)\end{array}$ & $\begin{array}{l}-.141 \\
(.869)\end{array}$ & $\begin{array}{l}-.111 \\
(.895)\end{array}$ & $\begin{array}{l}-.125 \\
(.883)\end{array}$ \\
\hline Asian & $\begin{array}{l}-.939^{* *} \\
(.391)\end{array}$ & $\begin{array}{l}-.960^{* *} \\
(.383)\end{array}$ & $\begin{array}{l}-.386 \\
(.680)\end{array}$ & $\begin{array}{l}-.395 \\
(.674)\end{array}$ \\
\hline Native American/other & $\begin{array}{l}-.503 \\
(.605)\end{array}$ & $\begin{array}{l}-.559 \\
(.572)\end{array}$ & $\begin{array}{l}-.306 \\
(.736)\end{array}$ & $\begin{array}{l}-.331 \\
(718)\end{array}$ \\
\hline Age & $\begin{array}{l}-.704 \\
(.495)\end{array}$ & $\begin{array}{l}-.891 \\
(.410)\end{array}$ & $\begin{array}{c}-2.209^{* * *} \\
(.110)\end{array}$ & $\begin{array}{c}-2.246^{* * *} \\
(.106)\end{array}$ \\
\hline Age squared & $\begin{array}{c}.011 \\
(1.012)\end{array}$ & $\begin{array}{c}.016 \\
(1.016)\end{array}$ & $\begin{array}{l}.049^{* * * *} \\
(1.050)\end{array}$ & $\begin{array}{l}.050^{* * *} \\
(1.051)\end{array}$ \\
\hline Family SES & $\begin{array}{c}-.369^{* * *} \\
(.691)\end{array}$ & $\begin{array}{c}-.368^{* * *} \\
(.692)\end{array}$ & $\begin{array}{c}-.218^{* * *} \\
(.804)\end{array}$ & $\begin{array}{c}-.216^{* * *} \\
(.806)\end{array}$ \\
\hline Urbanicity & $\begin{array}{c}.186 \\
(1.204)\end{array}$ & $\begin{array}{c}.161 \\
(1.174)\end{array}$ & $\begin{array}{l}-.002 \\
(.998)\end{array}$ & $\begin{array}{l}-.011 \\
(.989)\end{array}$ \\
\hline Neighborhood poverty & $\begin{array}{l}.719^{* * *} \\
(2.053)\end{array}$ & $\begin{array}{l}.695^{* * *} \\
(2.004)\end{array}$ & $\begin{array}{l}.447^{* * * *} \\
(1.563)\end{array}$ & $\begin{array}{l}.440^{* * *} \\
(1.552)\end{array}$ \\
\hline Lives with both biological parents & $\begin{array}{c}-.806^{* * *} \\
(.447)\end{array}$ & $\begin{array}{c}-.788^{* * *} \\
(.455)\end{array}$ & $\begin{array}{c}-.431^{* * * *} \\
(.650)\end{array}$ & $\begin{array}{c}-.426^{* * *} \\
(.653)\end{array}$ \\
\hline GPA & $\begin{array}{c}-1.541^{* * * *} \\
(.214)\end{array}$ & $\begin{array}{c}-1.524^{* * * *} \\
(.218)\end{array}$ & $\begin{array}{c}-.950^{* * *} \\
(.387)\end{array}$ & $\begin{array}{c}-.940^{* * *} \\
(.391)\end{array}$ \\
\hline Self-control & $\begin{array}{l}.052^{* * *} \\
(1.053)\end{array}$ & $\begin{array}{c}.026 \\
(1.026)\end{array}$ & $\begin{array}{l}-.011 \\
(.989)\end{array}$ & $\begin{array}{l}-.021^{*} \\
(.979)\end{array}$ \\
\hline Violence & & & & \\
\hline Violent victimization (W1) & - & $\begin{array}{c}.166^{*} \\
(1.180)\end{array}$ & - & $\begin{array}{c}.059 \\
(1.061)\end{array}$ \\
\hline Violent perpetration (W1) & - & $\begin{array}{l}.367^{* * *} \\
(1.443)\end{array}$ & - & $\begin{array}{l}.173^{* * *} \\
(1.188)\end{array}$ \\
\hline Violent victimization (W3) & $\begin{array}{c}.185 \\
(1.203)\end{array}$ & $\begin{array}{c}.111 \\
(1.117)\end{array}$ & $\begin{array}{l}.272^{* * * *} \\
(1.312)\end{array}$ & $\begin{array}{c}.237^{*} \\
(1.268)\end{array}$ \\
\hline Violent perpetration (W3) & $\begin{array}{c}.200^{*} \\
(1.220)\end{array}$ & $\begin{array}{c}.118 \\
(1.125)\end{array}$ & $\begin{array}{l}-.009 \\
(.991)\end{array}$ & $\begin{array}{l}-.045 \\
(.956)\end{array}$ \\
\hline Constant & $14.596^{*}$ & $16.502^{*}$ & $28.463^{* * * *}$ & $28.782^{* * * *}$ \\
\hline
\end{tabular}

${ }^{*} p<.05 ;{ }^{* *} p<.01 ;{ }^{* * *} p<.001$. 
the amount of social control in their lives (Hirschi, 1969) while simultaneously increasing the amount of time spent with potentially like-minded peers (Burgess \& Akers, 1966).

The relationship between past and future violence and victimization and their mutual influence on educational attainment provides further support for my overall hypothesis that these aspects of violent behavior should be considered as separate factors. When all four measures of violence and victimization are included in the analysis, adolescent violence and victimization both increase the risk of dropping out of school, while contemporary violence and victimization do not matter. My findings also indicate that adolescent violence remains associated with limited attainment, and while adolescent victimization does not matter in this respect, contemporaneous victimization does.

\section{Discussion}

Prior research on the relationship between youth violence, educational achievement, and the idea of emerging socioeconomic attainment more broadly has largely focused on the direct effect of violent victimization and the indirect effect of violent perpetration. Adolescent violent victimization has been shown to reduce the likelihood of socioeconomic success in adulthood through its effect on school performance (Macmillan, 2000, 2001; Macmillan \& Hagan, 2004). Adolescent violent victimization may also trigger an early entry into adult roles, which includes leaving school to enter the labor market (Hagan \& Foster, 2003).

As for the relationship between one's own violent behavior and the likelihood of future economic success, past research has not directly examined this relationship. Instead, research in this area has linked violence and status attainment as co-morbid outcomes. For example, violent offending and failure to succeeded educationally may be the result of low self-control (Gottfredson \& Hirschi, 1990), lack of commitment to conventional behavior (Hirschi, 1969), or perhaps even because of prior victimization (Lauritsen et al., 1991; Hagan \& Foster, 2001; Haynie et al., 2009).

My findings indicate that adolescent violent perpetration and victimization are both long-term risk factors associated with limited educational achievement in early adulthood. In general, violent adolescents are more likely to drop out of school or stop at a high school diploma versus going to college. Violent victimization is also associated with limited educational achievement, but its influence appears to be more immediate-victimized adolescents are more likely to drop out of school; victimized young adults are more likely to stop their educational achievement at high school. Moreover, neither perpetration nor victimization dominates this relationship. Depending on the outcome and the point at which either aspect of violence occurred, perpetration may matter more than victimization, or vice-versa.

These findings support prior research on the relationship between victimization and emerging socioeconomic status and contribute to this growing area of research in several important ways. According to my findings and consistent with prior research (Macmillan \& Hagan, 2004), adolescent violent victimization can seriously jeopardize future economic success by increasing the risk of dropping out of school and, for adolescents who do finish high school, reducing their likelihood of going to college. Furthermore, victimization affects young men and women differently; victimization has a stronger effect on dropping out of high school for boys and a stronger effect on college attendance for girls.

Violence also has a substantial influence on educational achievement. In fact, the relationship between violent perpetration and both educational outcomes is more consistent throughout these analyses than the relationship between victimization and educational achievement. There is no instance where one's own violent behavior in adolescence does not matter. However, violence in early adulthood does not have any direct relationship with educational attainment according to these analyses. The importance of these effects should not be overlooked: if there is something unique to being a perpetrator versus being a victim of violence, then this means that violence is much more complex than previously thought, and violence overall should not be treated as a nebulous behavior. Without question, perpetration matters as much as victimization.

One major question that this project does not address is how these relationships may differ based on socioeconomic status. Throughout these analyses, both neighborhood poverty and family SES influence educational achievement in the logical ways: neighborhood poverty is associated with increased likelihood of dropping out of school and not going to college, while the opposite is true for family SES. The next step in this line of inquiry is to explore how violence and victimization can affect emerging socioeconomic attainment in different socioeconomic contexts. It may be the case that violent experiences in impoverished settings have no effect on educa- 
tional achievement-violence, victimization, and lack of educational success may all be symptomatic of living in poverty (i.e., Anderson, 1999), and so maybe violence and victimization won't directly lead to educational failure in this setting. On the other hand, maybe the effect of violence and victimization on status attainment is exacerbated in instances of extreme poverty. Further still, Hay, Fortson, Hollist, Altheimer, and Schaible (2006) showed that community disadvantage could affect family processes, and so future research on how neighborhood poverty may affect the processes outlined here should also focus on the role of family socioeconomic status, and whether and how the relationship between neighborhood poverty was buffered or exacerbated by family poverty.

\section{Acknowledgements}

This research uses data from Add Health, a program project directed by Kathleen Mullan Harris and designed by J. Richard Udry, Peter S. Bearman, and Kathleen Mullan Harris at the University of North Carolina at Chapel Hill, and funded by grant P01-HD31921 from the Eunice Kennedy Shriver National Institute of Child Health and Human Development, with cooperative funding from 23 other federal agencies and foundations. Special acknowledgment is due Ronald R. Rindfuss and Barbara Entwisle for assistance in the original design. Information on how to obtain the Add Health data files is available on the Add Health website (http://www.cpc.unc.edu/addhealth). No direct support was received from grant P01-HD31921 for this analysis.

\section{References}

Agnew, R. (1992). Foundation for a General Strain Theory of Crime and Delinquency. Criminology, 30, 47-88. http://dx.doi.org/10.1111/j.1745-9125.1992.tb01093.x

Agnew, R. (2001). Building on the Foundation of General Strain Theory: Specifying the Types of Strain Most Likely to Lead to Crime and Delinquency. Journal of Research in Crime and Delinquency, 38, 319-361. http://dx.doi.org/10.1177/0022427801038004001

Agnew, R., Timothy, B., Wright, J. P., \& Cullen, F. T. (2002). Strain, Personality Traits, and Delinquency: Extending General Strain Theory. Criminology, 40, 43-72. http://dx.doi.org/10.1111/j.1745-9125.2002.tb00949.x

Anderson, E. (1999). Code of the Street: Decency, Violence, and the Moral Life of the Inner City. W.W. Norton \& Company, New York.

Apel, R., \& Kaukinen, C. (2008). On the Relationship between Family Structure and Antisocial Behavior: Parental Cohabitation and Blended Households. Criminology, 46, 35-70. http://dx.doi.org/10.1111/j.1745-9125.2008.00107.x

Bearman, P. S., \& Moody, J. (2004). Suicide and Friendship among American Adolescents. American Journal of Public Health, 94, 89-95. http://dx.doi.org/10.2105/AJPH.94.1.89

Bernburg, J. G., \& Krohn, M. D. (2003). Labeling, Life Chances, and Adult Crime: The Direct and Indirect Effects of Official Intervention in Adolescence on Crime in Early Adulthood. Criminology, 41, 1287-1318. http://dx.doi.org/10.1111/j.1745-9125.2003.tb01020.x

Bernburg, J. G., Krohn, M. D., \& Rivera, C. J. (2006). Official Labeling, Criminal Embeddedness, and Subsequent Delinquency: A Longitudinal Test of Labeling Theory. Journal of Research in Crime and Delinquency, 43, 67-88. http://dx.doi.org/10.1177/0022427805280068

Demuth, S., \& Brown, S. L. (2004). Family Structure, Family Processes, and Adolescent Delinquency: The Significance of Parental Absence versus Parental Gender. Journal of Research in Crime and Delinquency, 41, 58-81. http://dx.doi.org/10.1177/0022427803256236

Giordano, P. C., Schroeder, R. D., \& Cernkovich, S. A. (2007). Emotions and Crime over the Life Course: A Neo-Meadian Perspective on Criminal Continuity and Change. American Journal of Sociology, 112, 1603-1661.

http://dx.doi.org/10.1086/512710

Gottfredson, M., \& Hirschi, T. (1990). A General Theory of Crime. Stanford, CA: Stanford University Press.

Hay, C., Fortson, E. N., Hollist, D. R., Altheimer, I., \& Schaible, L. M. (2006). The Impact of Community Disadvantage on the Relationship between the Family and Juvenile Crime. Journal of Research in Crime and Delinquency, 43, 326-356. http://dx.doi.org/10.1177/0022427806291262

Haynie, D. L., Petts, R. J., Maimon, D., \& Piquero, A. R. (2009). Exposure to Violence in Adolescence and Precocious Role Exits. Journal of Youth and Adolescence, 38, 269-286. http://dx.doi.org/10.1007/s10964-008-9343-2

Hirschi, T. (1969). Causes of Deliquency. Oakland, CA: University of California Press.

Lauritsen, J. L., Sampson, R. J., \& Laub, J. H. (1991). The Link between Offending and Victimization among Adolescents. 
Criminology, 29, 265-292. http://dx.doi.org/10.1111/j.1745-9125.1991.tb01067.x

Macmillan, R., \& Hagan, J. (2004). Violence in the Transition to Adulthood: Adolescent Victimization, Education and Socioeconomic Attainment in Later Life. Journal of Research on Adolescence, 14, 127-158. http://dx.doi.org/10.1111/j.1532-7795.2004.01402001.x

Macmillan, R. (2000). Adolescent Victimization and Income Deficits in Adulthood: Rethinking the Costs of Criminal Violence from a Life-Course Perspective. Criminology, 38, 553-588. http://dx.doi.org/10.1111/j.1745-9125.2000.tb00899.x

Macmillan, R. (2001). Violence and the Life Course: The Consequences of Victimization for Personal and Social Development. Annual Review of Sociology, 27, 1-22. http://dx.doi.org/10.1146/annurev.soc.27.1.1

Matsueda, R. L., \& Heimer, K. (1997). A Symbolic Interactionist Theory of Role-Transitions, Role-Commitments and Delinquency. In T. Thornberry (Ed.), Developmental Theories of Crime \& Delinquency-Advances in Criminological Theory (pp. 163-213). Piscataway, NJ: Transaction Publishers.

Perrone, D., Sullivan, C. J., Pratt, T. C., \& Margaryan, S. (2004). Parental Efficacy, Self-Control and Delinquency: A Test of a General Theory of Crime on a Nationally Representative Sample of Youth. International Journal of Offender Therapy and Comparative Criminology, 48, 298-312. http://dx.doi.org/10.1177/0306624X03262513

Rosenberg, M., Schooler, C., \& Schoenbach, C. (1989). Self-Esteem and Adolescent Problems: Modeling Reciprocal Effects. American Sociological Review, 54, 1004-1018. http://dx.doi.org/10.2307/2095720

Royston, P. (2004). Multiple Imputation of Missing Values. Stata Journal, 4, 227-241.

Sampson, R. J., \& Laub, J. H. (1992). Crime and Deviance in the Life Course. Annual Review of Sociology, 18, 63-84. http://dx.doi.org/10.1146/annurev.so.18.080192.000431

Schreck, C. J., Stewart, E. A., \& Osgood, D. W. (2008). A Reappraisal of the Overlap of Violent Offenders and Victims. Criminology, 46, 871-906. http://dx.doi.org/10.1111/j.1745-9125.2008.00127.x

Sewell, W. H., \& Shah, V. P. (1968). Social Class, Parental Encouragement and Educational Aspirations. American Journal of Sociology, 73, 559-572. http://dx.doi.org/10.1086/224530 
Scientific Research Publishing (SCIRP) is one of the largest Open Access journal publishers. It is currently publishing more than 200 open access, online, peer-reviewed journals covering a wide range of academic disciplines. SCIRP serves the worldwide academic communities and contributes to the progress and application of science with its publication.

Other selected journals from SCIRP are listed as below. Submit your manuscript to us via either submit@scirp.org or Online Submission Portal.
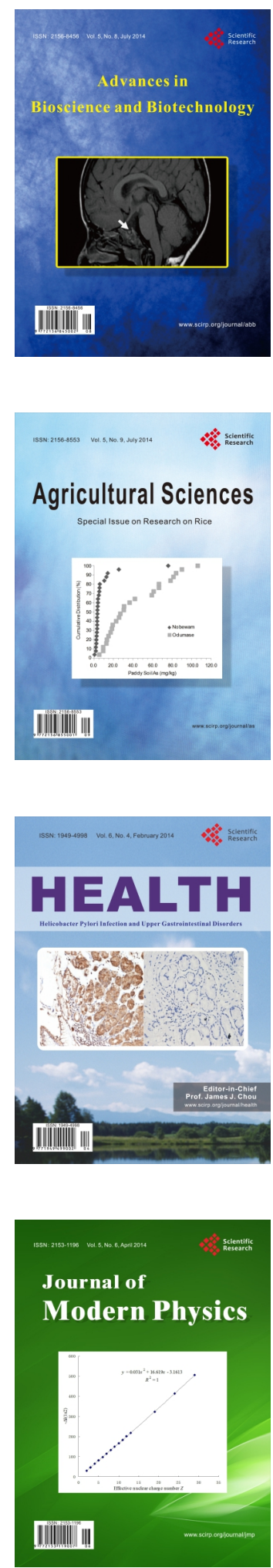
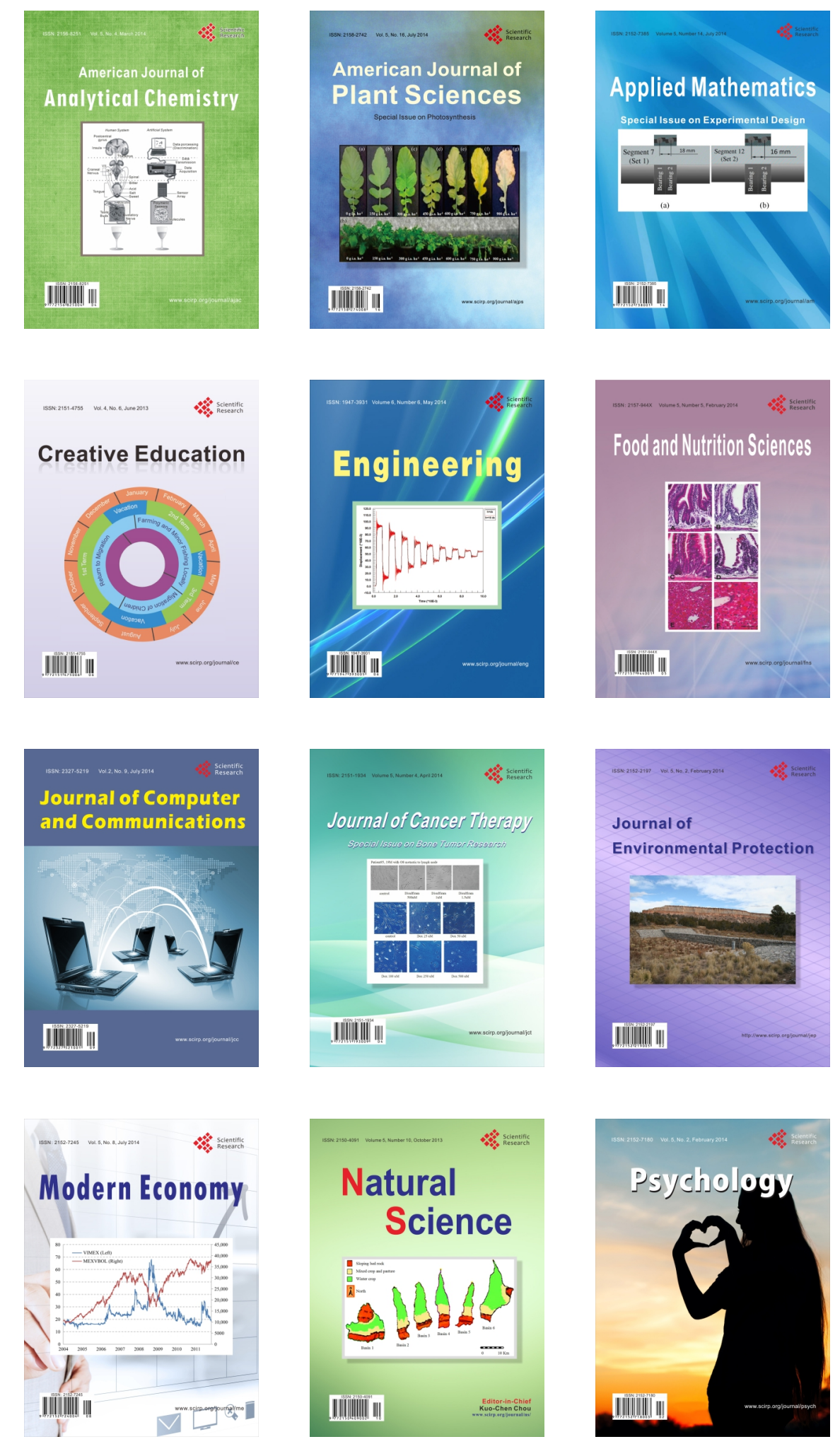